\title{
THE EFFEC OF CONTEXTUAL TEACHING AND LEARNING METHOD IN WRITING ENGLISH PARAGRAPH AT ENGLISH DEPEARTMENT FKIP NDMMENSEN PEMATANGSIANTAR
}

\author{
Marnala Pangaribuan' \\ Fakultas Keguruan dan Ilmu Pendidikan Universitas HKBP Nommensen, Pematangsiantar \\ marnalapangaribuan|5国gmail.com '
}

\section{Info Artikel}

Diterima : 18 September 2020

Revisi : 22 Dktober 2020

Terbit : 18 Desember 2020

\section{Keywords:}

Contextual Teaching, Learning

Method, Writing, Writing

Paragraph.

\section{Kata Kunci:}

Pengajaran Kontekstual, Metode Pembelajaran, Menulis, Menulis Paragraf.

\section{Corresponding Author :}

Marnala Pangaribuan, E-mail : marnalapangaribuanl5回gmail .com

Abstract

This study is aimed to describe the Effect of Contextual Teaching and Learning Method an the Students' ability in Writing Paragraph at English Department of FKIP Nommensen Pematangsiantar. This is an experimental research which conducted in quantitative analysis. The population of this research was Group $C$ and $D$ students of English Department FKIP Nommensen Pematangsiantar academic year 2018/2019. There were two classes. The samples of this research were taken from two classes. They were group $\complement$ that consists of 45 students stated as the experimental class, and group $D$ that consist of 25 students stated as the control class. After analyzing the data, the writer found that there was a significant effect of using Contextual Teaching and Learning Method to the students' ability in writing paragraph. The Mean Score was II,72 and the value of t-test was higher than t-table (t-test > t-table), 5,208 > 1,596. Ha (Alternative Hypothesis) was accepted and Ho (Null Hypothesis) was rejected. It can be concluded that by using contextual teaching and learning method, the students were encouraged to do writing paragraph in their daily life. The students have abilities to identify their еггог in writing.

\section{Abstrak}

Penelitian ini bertujuan untuk mengetahui pengaruh pengajaran dan pembelajaran metade kontekstual terhadap kemampuan mahasiswa dalam menulis paragraf di program studi Pendidikan Bahasa Inggris FKIP Nommensen Pematangsiantar. Penelitian ini adalah penelitian eksperimental dengan menggunakan analisis kuantitatif. Populasi penelitian ini adalah mahasiswa Prodi Bahasa Inggris Group E dan Group D yang terdiri dari 25 mahasiswa sebagai control class. Setelah menganalisis data, peneliti menemukan bahwa ada pengaruh yang signifikan dengan mengunakan metade pembelajaran dan pengajaran kontekstual terhadap kemampuan mahasiswa dalam menuliskan paragraf. Rata-rata skar pemerolehan adalah II,72 dan hasil t-test lebih tinggi dari t-table ( t-test >t-table), 5,208 > 1,996. $\mathrm{Ha}$ ( alternatif hipotesis telah diterima dan $\mathrm{Ho}$, (nol hipotesis) ditalak. Maka dapat disimpulkan bahwa dengan menggunakan metade kontekstual pembelajaran dan pengajaran., mahasiswa lebih termotivasi untuk menulis paragraph. 


\section{INTRODULTION}

Learning a language takes complex abilities (Hun and Ellis 2004; 289). In learning to write students operate their complex capabilities from exercising allocating words into sentences, then how to put sentences into a paragraph and putting of paragraph into a text are altogether a complex process.

Writing is a complex process that involves a range of skill and tasks. Although writing is often used to clarify and express personal thoughts and feelings, it is used primarily to communicate with others. Therefore, writing is a power full instrument part for students to use to express their thoughts, feelings, and judgments about what they have read, seen or experienced.

Based on the writer's experience in teaching writing paragraph at the University, it is not easy for the students to write well in English. Most of them were not interested in writing and were not giving attention to process of teaching writing so that they had a lot of problems when writing. Students found some problems in writing a paragraph, for example difficult in inventing a main topic, inventing a controlling idea, farmulating the topic sentence, collecting the data and formulating the concluding sentence.

One of the biggest problems in student writing paragraph is that student often fail to prove their points, with concrete details. And also same students have difficulty communicating ideas, events and experience because a limited repertaire of spoken and written English. The writer transfers his/her thaught. opinion, or comment in written form, which is expected to be comprehended by the reader.

Consideration to the statement and the problems above, the are many methad can be used by lecturer to teach writing subject. Such as, Students-Team Learning, Small Group Discussion, Students-Team Achievement-Division, Jigsaw, Contextual Teaching and Learning, etc. The Contextual Teaching and Learning is chosen and considered as the most appropriate technique to be applied to help students covering their problems in writing paragraph and develop the students ability in writing.

Actually, it is not easy to teach language especially wiring without using the suitable method because a large number of methods are based on ideas of how languages aгe learned. There are many methods of language teaching that may be selected for teaching writing paragraph. One of them which can be proved in writing skill is Contextual Teaching and Learning (¿TL).

CTL is an educational process that aims to help student see meaning in the academic subject with the context of their daily lives, that is, with the context of their personal, social, and cultural circumstances. To achieve this aim, the system encompasses the following eight components: making meaningful connections, doing significant work, self-regulated learning, and collaborating, critical and creative thinking, nurturing the individual, reaching high standards, and using authentic assessment (Johnsan, 2002:25).

From the statement, the writer says that CTL is the methad that helps students relate subject matter content to the real world situations and motivate students to make connections between knowledge and its applications to their lives as family members, citizens, and workers and engage in the hard work that learning requires. In such an enviranment, student will discaver meaningful relationship between abstract ideas and practical applications in the context of the real world.

The essence of CTL is to study by the concept to help teacher to relate between materials that teaching with the real situation of students and to motivate the students to make the correlation between their knowledge with its application. CTL also have the principles and the application will be dane by involving seven 
principle components in effective learning namely constructivism, inquiry, questioning, community, modeling, reflection, and authentic assessment.

In teaching learning theory, this methad is based on constructivism ideolagy. In teaching and learning madel, students construct their own knowledge by testing ideas based an prior knowledge and experience, applying these ideas to a new situation, and integrating the new knowledge gained with preexisting. Constructivism calls for active participation in problem solving and critical thinking regarding an authentic learning activity that the students find the relevant and engaging the intellect construct. In ather word, this method is regarded as the effective methad in teaching paragraph writing.

Based on the explanation above, the researcher hypothesized that the Contextual Teaching and Learning Method will be appropriate as the method in teaching writing paragraph. By using Contextual Teaching and Learning Method the students writing ability would be better. The writer proposed a research entitled: "The Effect of Contextual Teaching and Learning Methad" in Writing English Paragraph. Therefore, in this research, the writer would like to know the effectiveness developing students' writing ability.

In a relation to the background of the research mentioned before, the problem of this research proposal is formulated as: "Is there a significant Effect of Contextual Teaching and Learning Method in Writing English Paragraph for the first year students of English Department FKIP Nommensen Pematangsiantar?

The hypothesis of the research is proposed in terms of alternative hypothesis $(\mathrm{Ha})$ and null hypothesis (Ho). They are:

a. Ha : Contextual Teaching and Learning Method significantly affects towards Writing English Paragraph at first year students at English department of FKIP Nommensen Pematangsiantar.

b. Ho : Contextual Teaching and Learning Methad does not significantly affect towards Writing English Paragraph at first year students at English department of FKIP Nommensen Pematangsiantar.

To avoid misunderstanding and misinterpretation, the research provides the explanation in respect to some important in the studies as follows:

a. Writing is productive language skill, it is the skill of a writer to communicate information to a reader or group of readers.

b. Contextual teaching and Learning Method is an educational process that aims to help students see meaning in the academic subject with the context of their daily life, that is with the context of their personal, sacial and cultural circumstances. (Jahnson, 2002:25)

c. A paragraph is a piece of writing containing atopic sentence, some supporting sentence and concluding sentence.

\section{THEORETICAL REVEW}

\subsection{Definition of Writing}

According to Westwoud (2008 : 56), "Writing is a process that involves lower-order transcription skills and higher-order camposing skills and can be extremely demanding for students because it calls upon many experiential, cognitive, linguistic, affective and psycho-motor memories and abilities." According to Lindstram, 
(in Peter Westwoud, 2008 : 57), " Writing is a complex skill involving multiple processes and abilities that problems can arise for some students. There is reason to suppose that the number of students with writing difficulties is even greater than the number experiencing difficulties in reading with understanding."

\subsection{The Elements of Writing Process}

According to Harmer (2004 : 4), "Writing is used for a wide variety of purpose it is produced in many different form". There are four elements of the writing process. They are :

I. Planning

Planning is the first step in daing writing. The writer plans what he is going to write or type in this step. It can be done by making detailed notes. When planning, the writer has no think three main issues: they are purposes, audience, content structure. Sa, planning is the first step that will be guide to the next step.

2. Drafting

Drafting is the second step in writing. It is an activity in which the writers will start their writing. This step refer to state your point in a topic of sentence, support your point, develop a single focus and organize sentences logically and add transition. They will write whatever in their mind. They will write as they know.

3. Editing (Reflecting and Revising)

Editing is the third step in doing writing. Editing can be done after drafting has done.it means that after daing drafting, the writer will read what has written to see where is warks and where is does not. It is to edit or to make about the writing, so that it can be easy to publish. It needs some corrections to same mistakes in the writing and to avoid the ambiguity in the writing.

4. Final Version

Once the writers have edited their draft, making the changes they consider to be necessary, they produce their final version. They may look considerably from both the original plan and the first draft, because things have changed in the editing process. But the writer is now ready to send the written text to the intended audience. So, there are four elements in the process of writing. To produce a gaod writing is to make sure that the four elements have been done well.

\subsection{Contextual Teaching and Learning}

Basically, CTL is a respond to Behaviorism Approach which emphasizes on the concept of stimulus respond with mechanical drills. "CTL is an educational process that aims to help student see meaning in the academic subject with the context of their daily lives, that is, with the context of their personal, social, and cultural circumstances" (Johnson, 2002:25). .

Jahnsan (2001:25) defines CTL is an educational process that aims to help student see meaning in the academic subject with the context of their daily lives, that is, with the context of their personal, sacial, and cultural circumstances. To achieve this aim, the system encompasses the following eight characteristics: making meaningful connections, daing significant work, self-regulated learning, and collaborating, critical and creative thinking, nurturing the individual, reaching high standards, and using authentic assessments" 
In addition, Berns and Erickson (200|:5) stated that "Contextual teaching and learning is a canception of teaching and learning that helps teachers relate subject matter content to real world situations and motivates students to make connections between knowledge and its applications to their lives as family members, citizens, and warkers and engage in the hard work that learning requires".

Meanwhile, The Washington State Consortium for Contextual Teaching and Learning, as cited in Nurhadi, Dkk. (2003:8), formulate the definition of CTL as "Contextual teaching is teaching that enables students to reinforce, expand, and apply their academic knowledge and skills in a variety of in-school and out-of school settings in order to solve the stimulated ar real-world problems".

Based on the previous four definitions, the writer concludes that CTL is the way or the concept of teaching that help teacher and students to relate subject matter to the real life situation and motivate student to connect and apply all aspect of learning into their role in real life. When we talked about context, most people say that it related to their social life. In the classroum teaching, CTL means teacher should present the student real world inside the classroum.

\subsection{The Components of CTL}

Nurhadi, Dkk (2003:34-51) explains seven components of CTL. These components underlying the implementation of the learning process by using CTL (contextual teaching and learning). The seven components include:

\section{l. Constructivism}

Constructivism is the foundation of CTL. The basic premise is that an individual learner must actively buildknowledge and skills. Canstructivism is the process of build or develops new knowledge in students' cognitive structure based on experience. "According to constructivism, the experience is met by the outside, but constructed by and from within oneself. Therefore, the experience is formed by two important factors i.e. the object becomes the subject of observation and ability to interpret the object" (Sanjaya, 2010:265). With those basic, learning have to be package become constructing process not only getting knowledge. In learning process, learners create their awn knowledge by active at the teaching process. Learners are the center of activity not the teacher.

According to Nurhadi (2003:34) in constructivism, the most important thing is getting strategy more than how many knowledge that they can get or memorize. So teachers have duty to facilitate those processes by:

a. Make the knowledge more relevant and meaningful for learners

b. Give opportunities for learners to find out and apply their own idea

c. Make the learners to apply their awn strategy in learning

\section{Inquiry}

In inquiry, the learning process is based on a search and discavery through a process of thinking systematic ally. Knowledge is not the result of considering a number of facts, but the outcome of the process of finding itself. Thus in the planning process, teachers are not preparing a number of materials to be memorized, but stimulate learning that allows students to find their own materials to be understond. 
The activities of inquiry are sickles, they are: I) Definite the problem, 2) Collecting data by observation, 3) Analyzing and presenting the data, writing, picture, report, scheme, and tables, 4) Communicating the data to the reader, classmates or another audience (NurhadiDkk, 2003:43).

\section{Questioning}

Learning is basically asking and answering questions. Questioning can be regarded as a reflection of the curiosity of every individual, while answering the questions reflects a person's ability in thinking. In the learning process, teacher daes not submit the infarmation for granted, but the lure for students to find themselves. Since questioning has very important role, because through the questions teachers can guide and lead students to find any material that is learned.

Sometimes, the teacher asks to the students before, during and after the lesson. At other times, they are posed effectively by the students to focus their own lesson, keep them engaged and help them monitar their understanding of what was learned. In a productive teaching learning, questioning activity are useful for checking students comprehension, solving problem faced by students, stimulating responses to the students, measuring students curiosity, focusing student attention, and refreshing students prior knowledge.

According to Orlich in Nurhadi, Dkk (2002:46) there are some importance questions in learning process in CTL method, they are:

a. Questioning is a general learning strategy and be able to applied to various learning.

b. Using and developing a systematic technique of question is believed tend to make learners' quality in learning better.

c. By classifying questions, teacher can determine the cognitive and affective levels which have to be had by learners.

d. By systematic techniques of questioning, teacher can determine the first knowledge level of the learners.

e. There are several questions for teacher to be given to the learners.

\section{Learning Community}

In the contextual teaching and learning CTL) implementation of learning communities can be dane by applying learning through study groups. "Students are divided into groups whose members are heterogeneous good views of learning ability and speed of learning" (Baker, et al., 2009:2). Let each other learn in their group, who quickly pushed to help the slow learners. Actually, learning community has the meaning that stated by Nurhadi, Dkk (2003:47) as follows:

a. Group of learning which communicate to share the idea and experience

b. Working together to solve the problem

c. The member of the group has the same responsibility

d. Create better situation and condition. So, child is able to learn with others

\section{Modeling}

"Modeling is a learning process as an example to demonstrate something that can be emulated by every student" (Nurhadi, Dkk, 2003:49). For example, the teacher gives examples of how to pronounce a fareign phrase. Gym teacher gave examples on how to throw a ball and so forth. Modeling activity also can be summarized into demonstrates the teacher's apinion and demonstrates how does the teacher want the student 
to learn. Model also come from outside, for example in learning English using native speakers. They become model in the classroum, how to pronoun when they are talking.

\section{Reflection}

"Reflection is the ways of thinking about what the students have learned and thinking about what the students have done in the past. Reflection is figuration of activity and knowledge that just have received" (Nurhadi, Dkk, 2003:5l). Teacher need to do the reflections in the end of teaching learning process. In the end of teaching learning process, teacher spends a little time and ask student to do the reflection. The realization of reflection can be done by giving direct statement about the information that acquired in the lesson, sume notes or journal on student book, some impression and suggestion from students about the learning process and discussion.

\section{Authentic Assessment}

Authentic assessment is the process by the teacher to gather information about the students learning progress. This assessment is needed to determine whether students are actually learning or not. Daes knowledge of student learning has a positive influence on both the intellectual and mental development of students.

"What have they already known?"So, the students are assessed through many ways, not only assessed their

\subsection{CTL Strategy}

Contextual Teaching and Learning (CTL) helps us relate subject matter content to real world situations and motivate students to make connections between knowledge and its applications to their lives as family members, citizens, and workers and engage in the hard work that learning requires. Hersh (IS45:IC) emphasizes six strategies of Contextual Teaching and Learning, they are:

\section{l. Problem-based Learning}

"Problem-based Learning is an instructional approach that uses real-world problems as a context for students to learn critical thinking and problem-solved skills and to acquire knowledge of the essential concepts of a course" Smith (2009:9). It means that CTL can begin with a simulated or real problem. Students use critical thinking skills and a systemic appraach to inquiry to address the problem or issue. Students may also draw upon multiple content areas to solve these problems. Worthwhile problems that are relevant to students' families, school experiences, workplaces, and communities hold greater personal meaning for students. In addition, Baker et al. (2005:Z) says "the problem-based learning can helps students the usefulness of certain skills because they are connected to a real-life problem-solving situation".

\section{Using Multiple Contexts}

According to Herhs (2009:10) says that "recognize the need for teaching and learning to occur in a variety of contexts such as home, community, and works sites". Theories of situated cognition suggest that knowledge can not be separated from the physical and sacial context in which it develops. How and where a persan acquires and creates knowledge is therefore very impartant. CTL experiences are enriched when students learn skills in multiple contexts (i.e. school, community, workplace, family).

\section{Drawing upon Student Diversity}


According to Hersh (2009:10) 'drawing upon student diversity is anchor teaching in students' diverse life-context". On the whole, our student population is becoming more diverse, and with increased diversity comes differences in values, sacial mores, and perspectives. These differences can be the impetus far learning and can add complexity to the CTL experience. Team collaboration and group learning activities respect students' diverse histories, broaden perspectives, and build inter-personal skills.

\section{Supporting Self-Regulated Learning.}

Ultimately, students must become lifelong learners. Lifelong learners are able to seek out, analyze, and use information with little to no supervision. To do so, students must become more aware how they process information, employ problem-solving strategies, and use background knowledge. Hersh (2009:ID) says "teach students to monitor and direct their awn learning so they become self-regulated learning". It means that, CTL experiences should allow far trial and еггог; provide time and structure for reflection; and provide adequate support to assist students to mave from dependent to independent learning.

\section{Using Interdependent Learning Groups}

Students will be influenced by and will contribute to the knowledge and beliefs of athers. Learning groups, ar learning communities, are established in warkplaces and schools in an effort to share knowledge, focus on goals, and allow all to teach and learn from each other. When learning communities are established in schools, educators act as coaches,facilitators, and mentors. "Students have different prior knowledge and experience, motivational factors, and personalities. These elements affect the ways in which students learn most effectively. ¿TL reaches a variety of learning styles in the classroum because the instructor can use different approaches within the experiential context, such as hands-on learning and collaborative learning" (Baker et al., 2008:2).

\section{RESEARCH METHODLDGY}

\subsection{Research Design}

This study was carried out by applying a quantitative approach with experimental design. There aгe two independent variable; the first is Contextual Teaching and Learning Method, the second is Conventional Method. Dependent variable is Students' writing paragraph.

\subsection{Population and Sample}

The population of this research is choose English Department students of FKIP Nommensen Pematangsiantar Academic Year 2018/2019 consist of 70 students. In this research proposal, the researcher choose two group from the first year academic 2018/2019 of English department FKIP Nommensen Pematangsiantar.

Population of group Academic Year 2018/2019 English Department Students of FKIP Nommensen Pematangsiantar.

\begin{tabular}{|c|c|c|c|}
\hline \multirow{2}{*}{ Group } & \multicolumn{2}{|c|}{ Gender } & \multirow{2}{*}{ Total of Student } \\
\cline { 2 - 3 } & Male & Female & \\
\hline$ᄃ$ & 8 & 37 & 45 \\
\hline$D$ & 14 & 11 & 25 \\
\hline
\end{tabular}

The Effec Of Contextual Teaching And Learning Method In Writing English Paragraph At English Depeartment Fkip Nommensen Pematangsiantar 


\section{\begin{tabular}{|c|c|c|c|}
\hline TOTAL & 22 & 48 & 70 \\
\hline
\end{tabular}}

\subsection{Research Instrument}

In this research the writer uses test as the instrument. The type of test that is used is free writing test. In this assessment, the teacher asked the students to write a paragraph based on the topic given which consist of 150 sentences. They are free to express their ideas based on what they have seen. After giving the test and classifying the test item, the writer analyzes the writing based on the component of writing.

\subsection{Techniques of Collecting Data}

There were some steps in order to get data in this research they are:

a. Pre Test

The students are given a pre test because pre test is used for matching the group experiment and control class. This test is given before the classes are regarded to have some ability.

b. Treatment

After test is given to the both group, the treatment is started. Each group is treated with different writing methad. The experimental group is taught by using contextual teaching and learning methad and the control group is taught without using contextual teaching and learning method.

c. Post Test

The test is also writing a paragraph. Post test is conducted after treatment. Here, for the experimental group, pictures are used in teaching writing paragraph to the students. For the control group, a conventional method is used post test to measure the students ability after treatment

\subsection{Technique of Analyzing Data}

In analyzing the data, the researcher used the result of pre-test and post-test. Then, they are analyzed to show the achievement of the data. After the research have finish done then here the steps to be taken in analyzing the data are below:

1. To Determine the mean of each group

2. $\mathrm{F}_{\text {test }}\left(\mathrm{F}_{\mathrm{t}}\right)$

\section{FINDINGS}

\section{Findings}

After analyzing the data, the problem Statement mentioned in the previous chapter were successfully testified. The findings of research is : There is a significant effect of using Contextual Teaching and Learning Method to students' ability in writing Paragraph. The alternative Hypothesis (Ha) was accepted and the Null Hypothesis $\left(H_{0}\right)$ was rejected. The value $t$-table was 1.996 while the value of $t$-test was 5.208 . it means that $t$ test (5.208) was higher than t-table at the level of significant of $0.05(1.996)$ or $5.208>1.996$. Teaching and Learning Method on students Writing English Paragraph at first year students at English Department of FKIP Nommensen Pematangsiantar

\section{CONCLUSIDNS}

After conducting and analyzing the data, result showed that there is a significant effect of using Contextual Teaching and Learning Method to students' ability in writing Paragraph. The alternative Hypothesis 
(Ha) was accepted and the Null Hypathesis ( $\left.\mathrm{H}_{0}\right)$ was rejected. The value $\mathrm{t}$-table was 1.996 while the value of $\mathrm{t}$ test was 5.208. it means that t-test (5.208) was higher than t-table at the level of significant of 0.05 (1.996) or 5.208 > 1.996. Using Contextual Teaching and Learning method is one of alternative ways that can be chosen by the teacher in teaching writing. Since Contextual Teaching and Learning provides opportunities to the students to be active in the class because they can write their ideas freely. By writing their materials, they can help their self to understand more about the materials.

\section{REFERENCES}

Ary, Donald, Introduction To Research In Education. New York: Library of Congress Cataloging In Publication Data.1979

Arikunta, Suharsimi, Prosedur Penelitian Suatu Pendekatan Praktek. Yogyakarta: Rineka Cipta. 2010

Baker, E.D., Hope, L.G \& Karandieef, K, Contextualized Teaching and Learning. Ohio: The Research and Planning Group Community Colleges Press. 2009

Berns G \& Patricia M Erickson, Contextual Teaching and Learning; Preparing Students for New Economy (vol.5). Bawling Green, DH: Bowling Green State University.200I

Brown, H Doughlas, Principle of Language Learning and Teaching. New Jersey: Prentice-Hall, Inc. 200I

Celce Marianne-Murcia. Teaching English as a second or Foreign Language, The Third Edition. Cambridge: Thamson Learning.2001

Consortium, The Washington State, Contextual Teaching and Learning. Washington: The Washington State Press.2003

Fulcher, Glen, Testing Second Language Speaking. Athena: Pearsan Education. 2003

Harris, David P. Testing English as Second Language. Michigan: University of Michigan Press.2009

Hornby, Dxford Advance Learner's Dictionary, Sixth Edition. Dxford: Dxfard University Press.2006

Heaton, J.B, Writing English Language Tests. New York. Longman. 2008

Harmer, Jeremy, How to Teach Writing. England : Longman. 2004.

Hersh, Susan, Contextual Teaching and Learning, Five Profiles Story. Thio State University Press.2009

Jahnsan, Elaine B, Contextual Teaching and Learning. New Mexica: Corwin Press.2002

Nurhadi, Dkk, Pembelajaran Kontekstual (Contextual Teaching and Learning. Malang: Penerbit Universitas Negeri

Malang. 2003

Richards, Jack ᄃ, Developing Classroum Speaking Activities; From Theory to Practice. Cambridge: Cambridge Edu. 2007

Sanjaya, H Wina, Strategi Pembelajaran Berorientasi Standar Proses Pendidikan. Jakarta: Kencana. 20I0 